\title{
石炭燃焼ボイラー排ガス中の $\mathrm{NO}_{x}, \mathrm{SO}_{x}$ の 同時除去パイロット試験 \\ -1981.9 .14 受理一
}

北海道工業開発試験所 井戸川清, 池田光二, 福田隆至

1. 緒言

前報 ${ }^{12)}$ 亿抒いてアルカリ土類化合物を含む $\mathrm{NO}_{x}$, $\mathrm{SO}_{x}$ の吸収剂として $\mathrm{MgSO}_{3}-\mathrm{Fe}(\mathrm{II})$-edta 系懸濁液 がそれらのすぐれた吸収性能を持つことを報告した。

本研究では, 上記, 懸濁液に $\mathrm{Mg}(\mathrm{OH})_{2}$ を添加し た吸収剂を用いて小型石炭ボイラー燃焼排ガス処理に 適用し, 吸収装置として充填塔を用いて $\mathrm{NO}_{x}$ 吸収性 能と操作条件との関係を明らかにした。

充填塔の充填物としては, 通常, 単位容積当りの表 面積の大きいラッシヒリングなどが用いられている が, 吸収液が懸濁液の場合には, 懸濁粒子が充填物表 面に付着して操作が不能になることが予想される。そ
こで, 充埧物としては, この点を考慮して垂直平行板 状充媜物（商品名サンパッキン）を用いた。な牧，充 媜物としてサンパッキンを用いた場合の充填塔の気相 物質移動係数と気液接触面積については, 公表された データが見あたらないので, $\mathrm{NaOH}$ 水溶液による $\mathrm{CO}_{2}$ の四収実験によってこれらを求め, これらと操作条件 との関係についても明らかにした。

\section{2. 実験装置}

$\mathrm{NO} x, \mathrm{SO}_{x}$ の同時除去パイロット試験装置のフロー シートをFig. 1 に示した。本装置は小型石炭燃焼ボイ ラ一, $\mathrm{NO}_{x}, \mathrm{SO}_{x}$ 吸収用の充垻塔, 吸収液調整槽, 固 液分離機等より構成されている。小型石炭ボイラーの

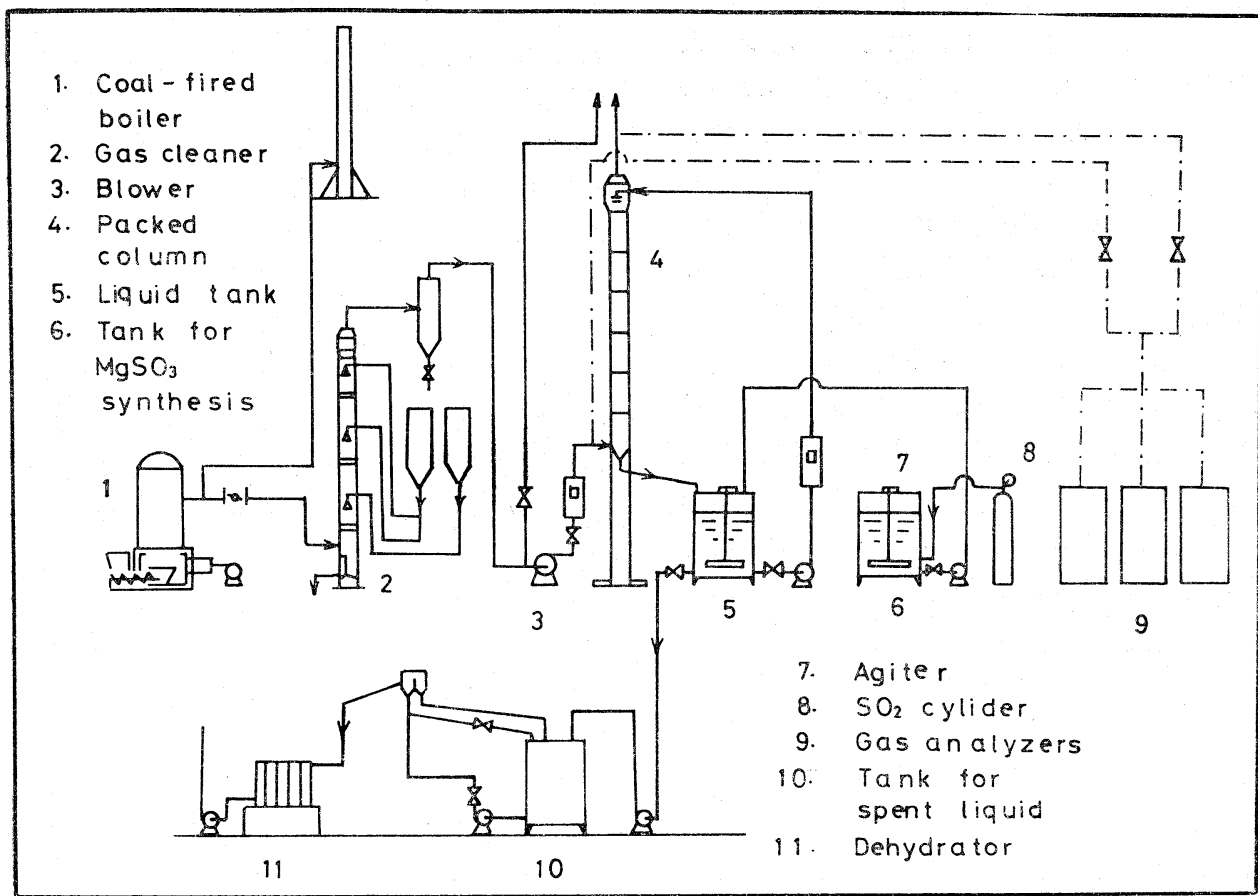

Fig. 1 Schematic diagram of pilot plant for simultaneous removal of $\mathrm{NOX}$ and SOx from flue gas of coal-fired boiler 


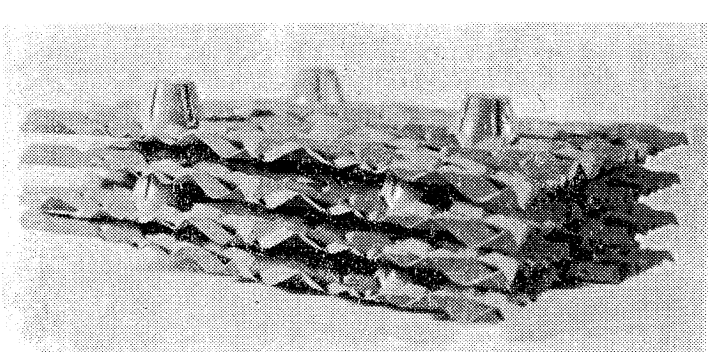

Fig. 2 Photograph of packing (SAN packing)

燃燒排沓 ス流量は毎時 $300 \mathrm{~N} \mathrm{~m}^{3}$ で，燃燒炬への石炭の 供給法は下込式である。吸收装虽として使用した充媜 菭は, 塔径 $\mathrm{Dt}=0.2 \mathrm{~m}$, 塔高 $\mathrm{Z}=3 \mathrm{~m}$ のステンレス 製で，塔上部にはデミスター，塔下部には液流下口と ガス吹込口を設けた。るた，塔本体は等間隔で 6 節に 仕切り，それぞれの節間には，多孔板 (孔径 $6 \mathrm{~mm} \phi$, 開孔比 0.2 , 正三角形配列) を取り付けた。充填物と してはFig. 2, に示した市販の塩化ビニール製充填物 (商品名 サンパッキン, SPC-16B，ピッチ16mm) を用いた。

\section{3. 測定法と操作法}

\section{1 気相物質移動係数と気液接触面積}

気相容量係数 $\mathrm{k}_{\mathrm{G}} \cdot \mathrm{a}$ と気液接触面積 $\mathrm{a}$ は $\mathrm{CO}_{2}-\mathrm{Na}$ $\mathrm{OH}$ 水溶液のガス吸収実験から，以下に示すような Wales ${ }^{14)}$ の方法によって求めた。空気で希积した $\mathrm{CO}_{2}$ の $\mathrm{NaOH}$ 水溶液による吸收速度 $\mathrm{N}_{\mathrm{A}} \cdot \mathrm{a}$ は次式で与 觉らる。

$$
\mathrm{N}_{\mathrm{A}} \cdot \mathrm{a}=\mathrm{K}_{\mathrm{G}} \cdot \mathrm{a} \cdot \mathrm{p}_{\mathrm{Alm}}
$$

また, 総括の吸収抵抗は気相抵抗と液相抵抗の和とし て次式で表される。

$$
1 / \mathrm{K}_{G} \cdot \mathrm{a}=\mathrm{H} / \beta \cdot \mathrm{k}_{\mathrm{L}}^{\circ} \cdot \mathrm{a}+1 / \mathrm{k}_{G} \cdot \mathrm{a}
$$

ここに, $\mathrm{K}_{G} \cdot \mathrm{a}$ は総括吸収容量係数 $\left(\mathrm{kmol} / \mathrm{Pa} \cdot \mathrm{m}^{3}\right.$ ・S), $\mathrm{H}$ はヘンリー定数 $\left(\mathrm{Pa} \cdot \mathrm{m}^{\mathrm{s}} / \mathrm{kmol}\right), \beta$ は反 応係数, $\mathrm{k}_{\mathrm{L}}{ }_{\mathrm{L}} \cdot \mathrm{a}$ は物理吸収に护汸る液相吸収容量係 数 $(1 / \mathrm{S}), \mathrm{p}_{\mathrm{A} 1 \mathrm{~m}}$ は充垻塔入口と出口の $\mathrm{CO}_{2}$ 分圧の 対数平均值である。 $\mathrm{CO}_{2}$ と $\mathrm{NaOH}$ の 反応の律速段 階は

$$
\mathrm{CO}_{2}+\mathrm{OH}^{-} \longrightarrow \mathrm{HCO}_{3}^{-}
$$

の反応であることが知られて打り, 本実験の $\mathrm{NaOH}$ 濃 度範围では， $\mathrm{CO}_{2}$ の吸収は $\mathrm{CO}_{2}$ と $\mathrm{OH}^{-}$に関して それぞれ1次の不可逆反応として取り扱らことができ $3^{4)}$ 。不可逆非瞬間 2 次反応の反応係数 $\beta$ は Eqs. (4)から(7)で与兄られるが， $\gamma>2 ， \beta_{\infty}>10 \gamma$ の条件では $\beta \simeq \gamma$ で近似できる

$$
\beta=\gamma \eta / \tanh \gamma \eta
$$

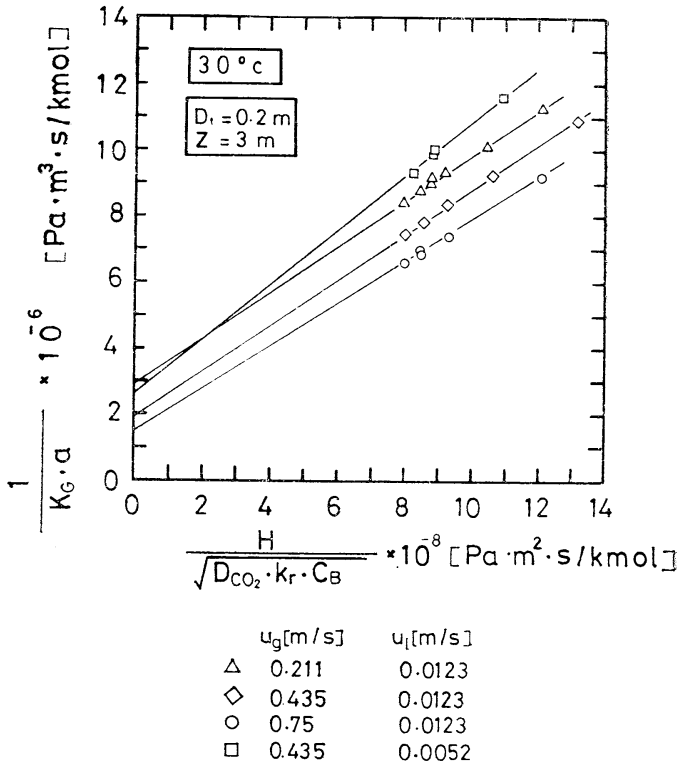

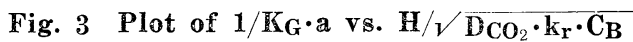

$$
\begin{aligned}
& \gamma=\sqrt{\mathrm{D}_{\mathrm{CO}_{2}} \cdot \mathrm{k}_{\mathrm{F}} \cdot \mathrm{C}_{\mathrm{B}}} / \mathrm{k}^{\circ}{ }_{\mathrm{L}} \\
& \eta=\sqrt{\left(\beta_{\infty}-\beta\right) /\left(\beta_{\infty}-1\right)} \\
& \beta_{\infty}=1+\left(\mathrm{D}_{\mathrm{B}} / \mathrm{D}_{\mathrm{A}}\right) \cdot\left(\mathrm{C}_{\mathrm{B}} / \mathrm{C}_{\mathrm{Ai}}\right)
\end{aligned}
$$

ここに, $\mathrm{k}_{\mathrm{r}}$ は反応速度定数 $\left(\mathrm{m}^{3} / \mathrm{kmol} \cdot \mathrm{s}\right), \mathrm{C}_{\mathrm{Ai}}$ は気

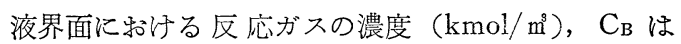
$\mathrm{OH}^{-}$の濃度 $\left(\mathrm{kmol} / \mathrm{m}^{3}\right), \mathrm{DCO}_{2}$ 快 $\mathrm{CO}_{2}$ の反応液中

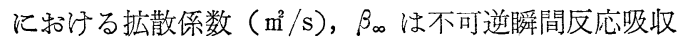
に対する $\beta$ を表す。 $\beta \simeq \gamma$ の場合，Eq. (2)は Eqs. (4)，（5）から次式となる。

$$
1 / \mathrm{K}_{\mathrm{G}} \cdot \mathrm{a}=\mathrm{H} / \mathrm{a} \cdot \sqrt{\mathrm{DCO}_{2} \cdot \mathrm{k}_{\mathrm{r}} \cdot \mathrm{C}_{\mathrm{B}}}+1 / \mathrm{k}_{\mathrm{G}} \cdot \mathrm{a}
$$

そこで, $\mathrm{NaOH}$ 水溶液の供給濃度を变化させた $\mathrm{CO}_{2}$ の吸収実験から，学孔ぞれの総括吸収容量係数 $\mathrm{K}_{\mathrm{G}} \cdot \mathrm{a}$ を算出し,その結果をEq. (8)の関係を用いて $1 / \mathrm{K}_{\mathrm{G}} \cdot \mathrm{a}$ と $\mathrm{H} / \sqrt{\mathrm{DCO}_{2} \cdot \mathrm{k}_{\mathrm{r}} \cdot \mathrm{C}_{\mathrm{B}}}$ 方眼紙上に点経し, Fig. 3 に 示した。同図から Eq. (8)の関係は直線で近似されて いる。したがって，この直線の勾配の逆数から気液接 触面積 $\mathrm{a}\left(\mathrm{m}^{2} / \mathrm{m}^{3}\right)$ を求め, 切片の逆数から気相容量 係教 $\mathrm{k}_{\mathrm{G}} \cdot \mathrm{a}\left(\mathrm{kmol} / \mathrm{Pa} \cdot \mathrm{m}^{3} \cdot \mathrm{s}\right)$ を求めた ${ }^{14)}$ 。また, $\mathrm{k}_{\mathrm{G}} \cdot \mathrm{a}$ と $\mathrm{a}$ とから気相物質移動係数 $\mathrm{k}_{\mathrm{G}}(\mathrm{kmol} / \mathrm{Pa}$. $\mathrm{m}^{2} \cdot \mathrm{s}$ ) を算出した。な拈，計算に用いた $\mathrm{k}_{\mathrm{r}}, \mathrm{D}_{\mathrm{CO}_{2}}$,

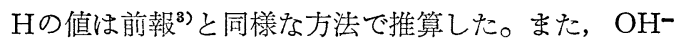
の濃度 $\mathrm{C}_{\mathrm{B}}$ は塔入口の $\mathrm{OH}^{-}$濃度である。

操作は気液向流式である。実験手順は以下のように して行った。空気を水蒸気で飽和したあと,フローメ 一タで計量する。ボンベからの $\mathrm{CO}_{2}$ の流量をマイク 
Table 1 Experimental conditions of gas absorption experiments on $\mathrm{NaOH}$ $\mathrm{CO}_{2}$ system

Temp. : $30^{\circ} \mathrm{C}$

Gas velocity: $0.21-0.75 \mathrm{~m} / \mathrm{s}$

Liquid velocity: $0.0052-0.0124 \mathrm{~m} / \mathrm{s}$

$\mathrm{CO}_{2}$ (inlet): $1.82-3.1 \%$

$\mathrm{NaOH}$ (initial conc.): $0.31-1.46 \mathrm{kmol} / \mathrm{m}^{3}$

ロバルブで調節し，空気と合流する。 $\mathrm{CO}_{2}$ と空気はス テンレス金網を充䱉したガス混合器を通して混合し た。 $\mathrm{NaOH}$ 水溶液はフローメータで計量したあと, ポンプで充填塔に導く。赤外線式 $\mathrm{CO}_{2}$ 計を用いて, 塔入口の供給ガス濃度が一定になったことを確かめた のら，実験を開始した。実験開始後，ただちにサンプ リング位置を塔出口側に切り替え, $\mathrm{CO}_{2}$ 濃度を連続的 に分析した。液サンプルは塔入口と出口で採取し，全 アルカリと水酸化物の濃度について分析した。

実験は $\mathrm{NaOH}$ の $\mathrm{Na}_{2} \mathrm{CO}_{3}$ への転換率が $20 \%$ 以下 になるように, $\mathrm{NaOH}$ 水溶液の供給濃度を設定した。 $\mathrm{CO}_{2}$ の吸収速度は $\mathrm{NaOH}$ 水溶液濃度の 減少速度か ら求わた。 $\mathrm{NaOH}$ 水溶液の供給濃度は1.5規定以下と した。実験条件をTable 1 に示す。

\section{$3.2 \mathrm{NO}_{x}$ の吸収試験}

$\mathrm{NO}_{x}, \mathrm{SO}_{x}$ の除去試験には, 小型石炭ボイラーから の燃燒排ガスを用いた。主煙道から分岐した排ガス を，京ず，水洗溚に導いて除應する。水洗塔出口ガス の温度の制御は，洗沙水の流量を調節することによっ て行った。水洗塔からの排水は活性炭, 砂, 砂利を充 填した沪過槽を通して処理した。水洗塔を出たガスを フローメータで計量し, 充填塔に導く。な特, $\mathrm{NO}_{x}$ お よび $\mathrm{SO}_{x}$ 濃度の比較的高い範囲の除去試験には, ボ ンベ入りの純 $\mathrm{NO}$ 括よび純 $\mathrm{SO}_{2}$ を水洗塔出口直後に 添加し, ガス混合器を通して排ガスと十分混合し, 所 定のガス濃度に設定した。吸収液はフローメータで計 量したあとポンプで充填塔に導く。液量 $0.5 \mathrm{~m}^{3}$ の吸収 液を, 吸収液タンクと充填塔間を循環して使用した。

ガス分析には, 日立堀場製赤外線吸收式の $\mathrm{NO} x / \mathrm{NO}$ 計および $\mathrm{CO}_{2}$ 計, 稵気ダンベル球式の $\mathrm{O}_{2}$ 計, 富士 電機製化学発光式の $\mathrm{NO} x / \mathrm{NO}$ 計和よび赤外線吸収式 の $\mathrm{SO}_{2}$ 計を用いた。吸収液の $\mathrm{pH}$ の測定には東亚電 波製の HIC-2 型の $\mathrm{pH}$ 計を用いた。吸収液中の $\mathrm{Fe}$

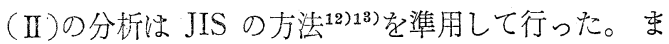
た，亜硫酸塩の分析は，以下のようにして行った。す なわち, 严硫酸塩の酸分解によって生成した $\mathrm{SO}_{2}$ ガ スを不活性ガスによって暴気し，これを一定量の沃素
Table 2 Experimental conditions of pilot plant test on simultaneous removal of NOx and SOx
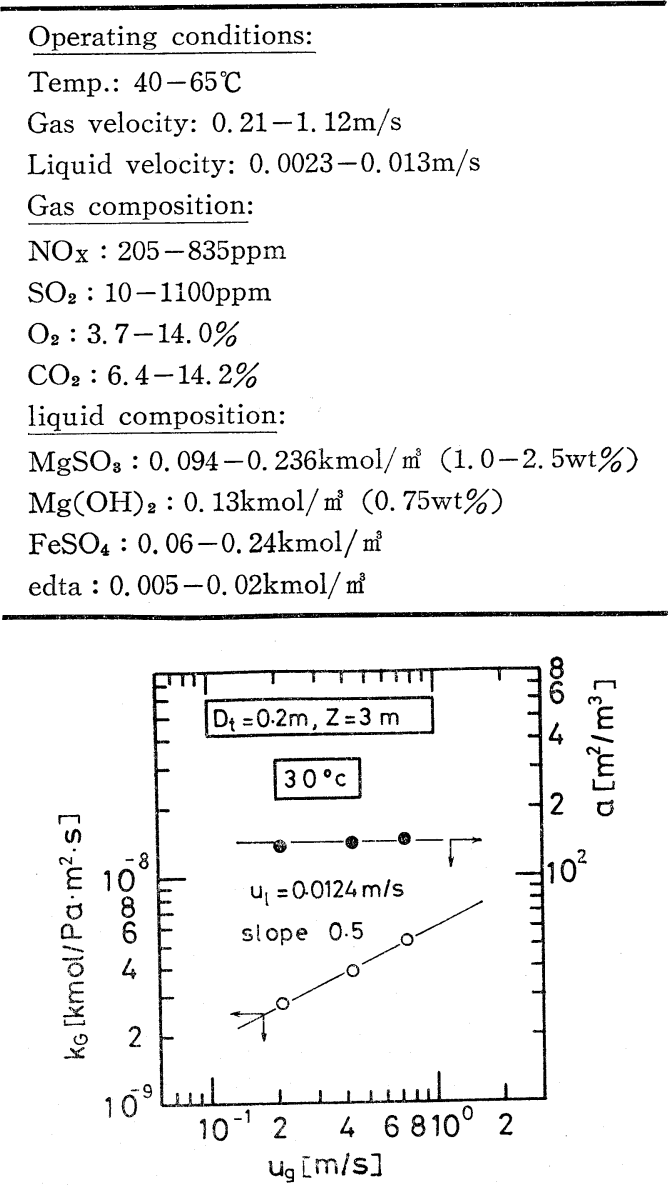

Fig. 4 Effect of $\mathrm{ug}_{\mathrm{g}}$ on $\mathrm{kg}_{\mathrm{G}}$ and a

規定液を入れた吸収びんに捕集する。沃素液をチオ硫 酸ナトリウム規定液で滴定し, 覀硫酸塩の濃度を求め た。

$\mathrm{NO}_{x}$ の吸収速度は, 塔入口と出口の $\mathrm{NO}_{x}$ 濃度差 と供給ガス流量から求めた。実験条件をTable 2 に示 す。吸収液の調整には, 市販の工業用薬品の $\mathrm{FeSO}_{4}$, edta, $\mathrm{Mg}(\mathrm{OH})_{2}$ を用いた。また, $\mathrm{MgSO}_{3}$ は $\mathrm{Mg}$ $(\mathrm{OH})_{2}$ 懸濁液と $\mathrm{SO}_{2}$ を化学量論比 1:1 で反応させ て合成した。

\section{4. 实験結颗}

\section{1 気相物質移動係数之気液接触面積}

気相物質移動係数 $\mathrm{k}_{\mathrm{G}}$ および気液接触面積 $\mathrm{a}$ と, ガ ス空荅速度 $u_{g}(\mathrm{~m} / \mathrm{s})$ との関係々 Fig. 4 に示した。 図示の関係から， $\mathrm{k}_{\mathrm{G}}$ は $\mathrm{ug}_{\mathrm{g}}$ の 0.5 乗に比例して増加 している。また，aは $u_{\mathrm{g}}$ によらずほぼ一定になって 


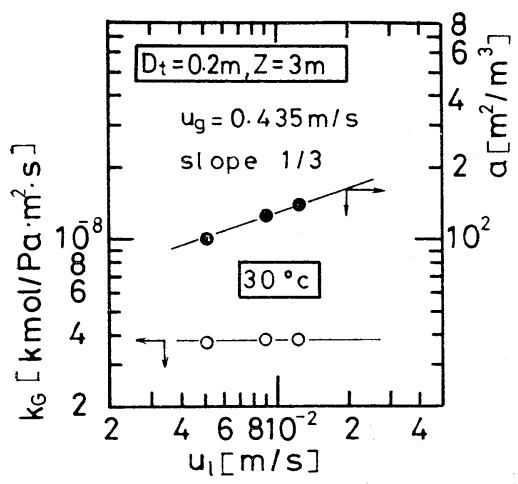

Fig. 5 Effect of $\mathbf{u}_{1}$ on $k_{G}$ and a

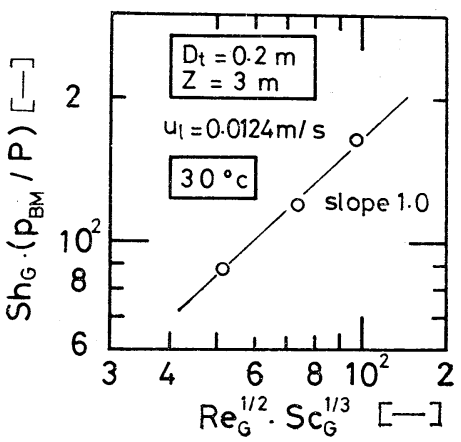

Fig. 6 Plot of $\operatorname{Sh}_{G} \cdot\left(\mathrm{p}_{\mathrm{BM}} / \mathrm{P}\right)$ vs. $\operatorname{Re}_{G^{1 / 2} \cdot \operatorname{Se}_{G}{ }^{1 / 3}}$

いる。

Fig. 5 に $\mathrm{k}_{\mathrm{G}}$ 特よび a に特よぼす液空塔速度 $\mathrm{u}_{1}(\mathrm{~m} /$ s）の影響を示した。本実験条件下においては， $\mathrm{k}_{\mathrm{G}}$ は $\mathrm{u}_{1}$ に影響されないことがわかった。また， $\mathrm{a}$ は $\mathrm{u}_{1}$ の 1/3乗に比例して増加している。Fig.4，5の結果から， $\mathrm{k}_{G}$ を無次元項で表示すれば，Fig. 6 のように整理さ れる。な物気相のシュミット数 $\mathrm{SC}_{G}\left(=\mu_{G} / \rho_{G} \cdot \mathrm{D}_{G}\right)$ のべき数としては，充填塔に関する既往の結果を用 い, 1/3乗9とした。したがって，Fig.4６６結果から シャーウッド数 $\mathrm{Sh}_{\mathrm{G}}\left(=\mathrm{k}_{\mathrm{G}} \cdot \mathrm{R} \cdot \mathrm{T} \cdot \mathrm{Dt} / \mathrm{D}_{\mathrm{G}}\right)$ と a それぞれ，次式で表される。

$$
\begin{gathered}
\mathrm{Sh}_{\mathrm{G}} \cdot\left(\mathrm{p}_{\mathrm{BM}} / \mathrm{P}\right)=\mathrm{K}_{1} \cdot \operatorname{Re}_{G^{1 / 2}} \cdot \mathrm{Sc}_{G^{1 / 3}} \\
\mathrm{a}=\mathrm{K}_{2} \cdot \mathrm{u}_{1}^{1 / 3}
\end{gathered}
$$

Fig. 6 に図示した結果から， $\mathrm{K}_{1}=1.67$ た，定数 $\mathrm{K}_{2}$ はFig.4，5 に図示した結果から， $\mathrm{K}_{2}=592 \mathrm{~S} \cdot \mathrm{m}^{-2}$ と なる。ここに, $\operatorname{Re}_{G}\left(=\mathrm{D}_{\mathrm{t}} \cdot \mathrm{u}_{\mathrm{g}} \cdot \rho_{\mathrm{G}} / \mu_{\mathrm{G}}\right)$ は気相のレイ ノルズ数, $\mathrm{p}_{\mathrm{BM}}$ は同伴ガスの平均分圧 $(\mathrm{Pa}), \mathrm{P}$ は全 圧 $(\mathrm{Pa}), \mathrm{D}_{\mathrm{G}}$ は気相中の着目したガスの拡散係数 $\left(\mathrm{m}^{2} /\right.$ $\mathrm{s}), \rho_{\mathrm{G}}$ はガスの密度 $\left(\mathrm{kg} / \mathrm{m}^{3}\right), \mu_{\mathrm{G}}$ はガスの粘度 $(\mathrm{Pa}$ -s）である。

\section{$4.2 \mathrm{NO}_{x}$ の吸収試験}

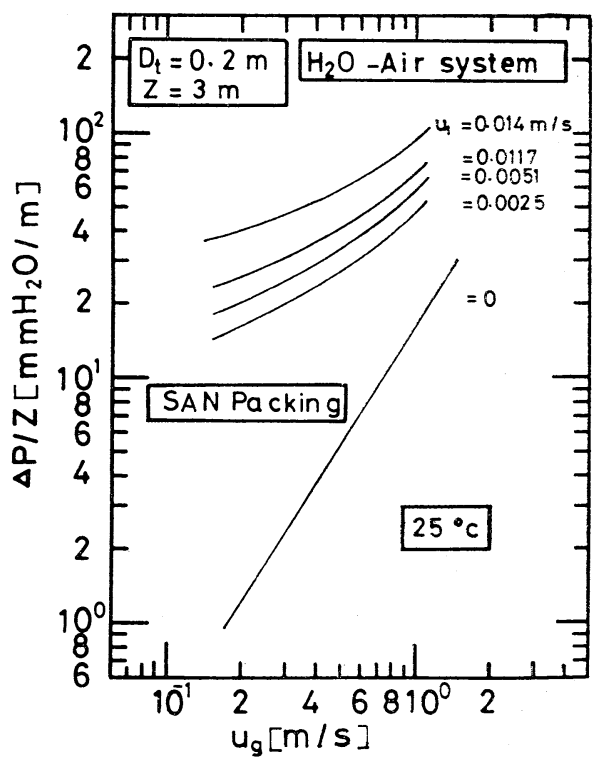

Fig. 7 Pressure drop of packed column

4.2.1 $\mathrm{NO}_{x}$ の吸収速度に拉よ洔す諸因子の影響 充填塔の単位高さ当りの圧力損失 $\Delta \mathrm{P} / \mathrm{Z}\left(\mathrm{mm} \mathrm{H}_{2} \mathrm{O} /\right.$ m）とガス空塔速度 $u_{g}$ との関係をFig. 7 に示した。 本実験条件下では，ローデイング点, フラッデイング 点は認められなかった。

Fig. 8, 9 に充填塔入口と出口の $\mathrm{NO}_{x}$ 濃度の記録 例を示した。入口の $\mathrm{NO}_{x}$ 濃度はFig. 8 に示すように， かなり変動している。これに対して, 出口の $\mathrm{NO}_{x}$ 濃 度はFig. 9 に示すよらに小さくなっている。

$\mathrm{NO}_{x}$ の吸収速度 $\mathrm{N}_{\mathrm{A}} \cdot \mathrm{a}\left(\mathrm{kmol} / \mathrm{m}^{3} \cdot \mathrm{s}\right)$ と, 充填 塔入口と出口に和㺭る $\mathrm{NO}_{x}$ の対数平均分圧 $\mathrm{p}_{\mathrm{Alm}}$ と の関係をFig.10に示した。 $\mathrm{N}_{\mathrm{A}} \cdot \mathrm{a}$ は $\mathrm{p}_{\mathrm{A} 1 \mathrm{~m}}$ にほぼ比 例して増加している。な拈, 本吸収液は, edta濃度に 対して Fe(II) を過剩に添加して調整しているが，こ の場合，錯体濃度 [Fe(II)-edta しいとして表している。

Fig.11に, $\mathrm{N}_{\mathrm{A}} \cdot \mathrm{a}$ と, $\mathrm{Fe}(\mathrm{II})$ と edta との震度比 を一定として edta 濃度を変化させた場合の $\mathrm{N}_{\mathrm{A}} \cdot \mathrm{a} /$ $\mathrm{p}_{\mathrm{A} 1 \mathrm{~m}}$ との関係を示した。 $\mathrm{N}_{\mathrm{A}} \cdot \mathrm{a} / \mathrm{p}_{\mathrm{A} 1 \mathrm{~m}}$ は錯体濃度 [Fe(II)-edta] が増加すると増加している。

$u_{\mathrm{g}}$ を一定とし， $\mathrm{N}_{\mathrm{A}} \cdot \mathrm{a} / \mathrm{p}_{\mathrm{Alm}}$ に特よぼす $\mathrm{u}_{1}$ の影響 を示したのが Fig.12でめる。 $\mathrm{N}_{\mathrm{A}} \cdot \mathrm{a} / \mathrm{p}_{\mathrm{Alm}}$ は $\mathrm{u}_{1}$ の增 加とともに増加している。

本試験では，充填塔入口排ガス中の $\mathrm{NO}_{x}$ 中に占め る $\mathrm{NO}$ の割合は 95\% 以上であり, $\mathrm{NO} \simeq \mathrm{NO}_{x}$ とみ なすことができる。そこで，Fig.10～12の結果と Mg 


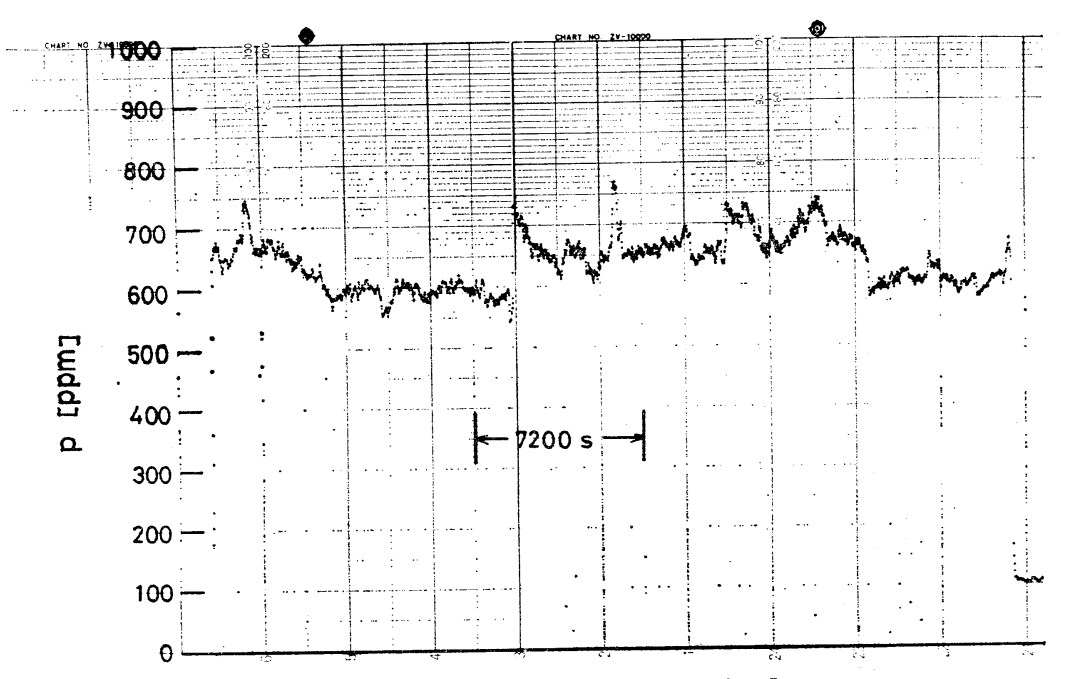

Fig. 8 Variation of NOx level in feed gas

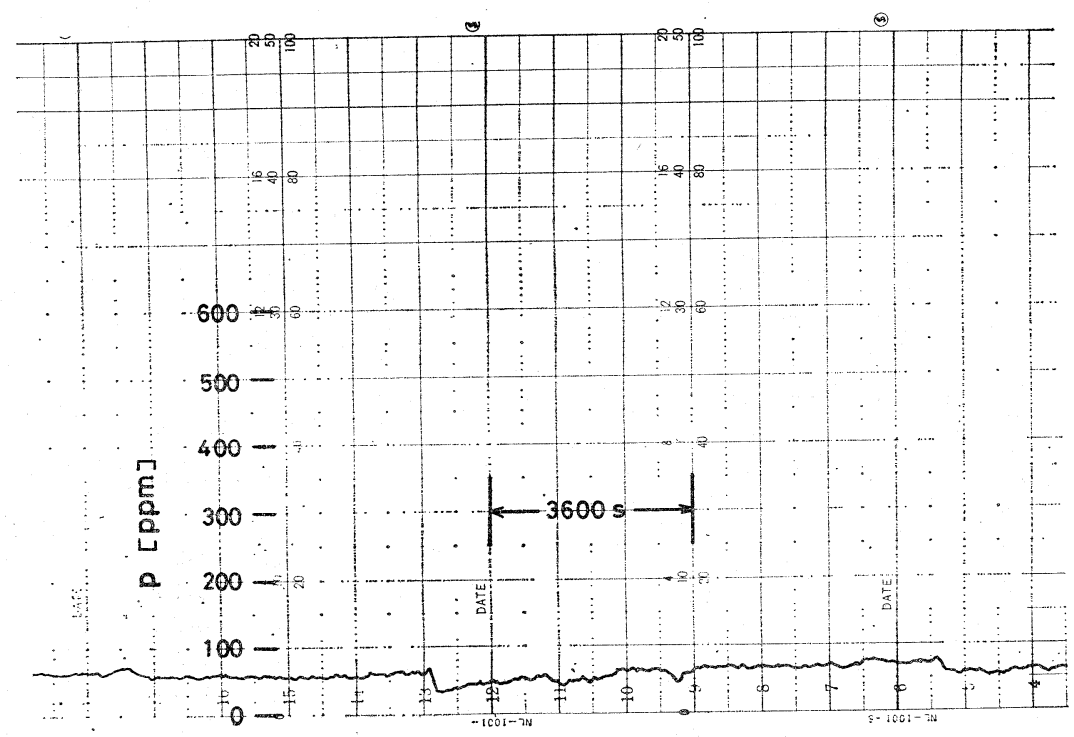

Fig. 9 Variation of NOx level at the outlet of the column

$\mathrm{SO}_{3}-\mathrm{Fe}$ (II)-edta 系㲘濁液による $\mathrm{NO}$ の反応吸收に 関する前報1の結果とから，充墤塔に执いても NOの 吸収は，迅速な不可逆擬一次反応を伴なら吸収として 進行していると推定される。この場合, $\mathrm{N}_{\mathrm{A}} ・ \mathrm{a}$ は次 式で表される。

$\mathrm{N}_{\mathrm{A}} \cdot \mathrm{a}=\mathrm{K}_{\mathrm{G}} \cdot \mathrm{a} \cdot \mathrm{p}_{\mathrm{Al} \mathrm{m}}=\frac{\mathrm{p}_{\mathrm{A} 1 \mathrm{~m}}}{\mathrm{H} / \mathrm{a} \cdot \sqrt{\mathrm{D}_{\mathrm{A}} \cdot \mathrm{k}_{1,1} \cdot \mathrm{C}_{\mathrm{B} 0}+1 / \mathrm{k}_{\mathrm{G}} \cdot \mathrm{a}}}$

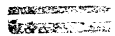

Eq. (11) 飞操作条件, 反応速度定数, 装置特性, 諸 物性值を代入し， $\mathrm{N}_{\mathrm{A}} \cdot \mathrm{a}$ 呿よび $\mathrm{N}_{\mathrm{A}} \cdot \mathrm{a} / \mathrm{p}_{\mathrm{A} 1 \mathrm{~m}}$ の推算
值をFig.10〜12の図中に実線で示した。これらの図よ り，推算值は実測值と比較的よく一致しており，上述 の推論が妥当であることを示している。なお，計算に 用いた $\mathrm{k}_{G}$ ，a の值は，それぞれ，Eqs. (9)，(10)よ り算出して用い， $\mathrm{k}_{1,1}$ は前報1の值を用いた。また, $\mathrm{D}_{\mathrm{A}}, \mathrm{H}$ は前報1)同様な方法で求めた。また， $\mathrm{C}_{\mathrm{B} 0}(=$ [Fe (II)-edta]) としては装置入口における吸收液中 の溶解 $\mathrm{Fe}(\mathrm{II})$ の濃度を実測し，これを錯体濃度 $\mathrm{C}_{\mathrm{B}}$ 。 として用いた。吸収液の性状などを Table 3 亿示す。 前述の上うに, $\mathrm{NO}_{x}$ 中の $95 \%$ 以上が $\mathrm{NO}$ であるので, 


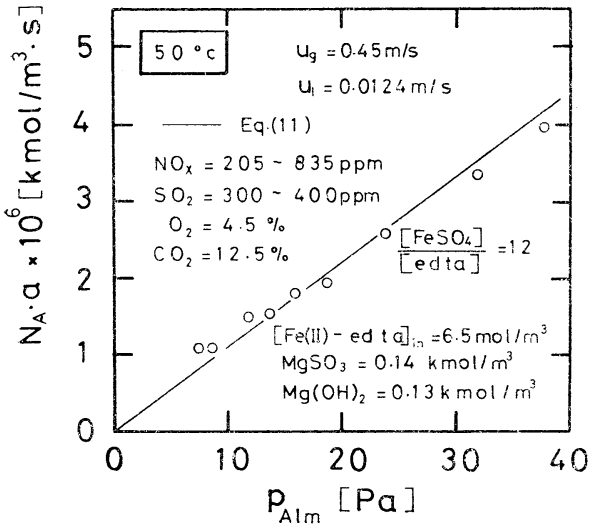

Fig. 10 Relation between $\mathrm{N}_{\mathrm{A}} \cdot \mathrm{a}$ and $\mathrm{p}_{\mathrm{Alm}}$

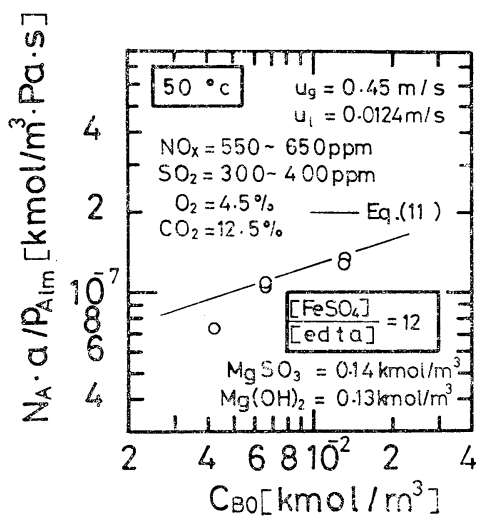

Fig. 11 Relation between $\mathrm{N}_{\mathrm{A}} \cdot \mathrm{a} / \mathrm{p}_{\mathrm{Alm}}$ and [Fe (II)-edta] chelate concentration $\mathrm{C}_{\mathrm{B} \text { 0 }}$

$\mathrm{NO}_{x}$ の物性值としては，NO の物性值で代替した。

$\mathrm{NO}_{x}$ 除去率 $\eta$ と液ガス比 $\mathrm{L} / \mathrm{G}$ (kg-liquid/ $\mathrm{kg}$ gas）との関係をFig.13に示した。クは L/G の増加 に伴ない増加するが，L/G が 30 以上になる之， は 90\%以上の高い值で湟定になっている。ぶス流量 $\mathrm{G}(\mathrm{kg} / \mathrm{s})$ が一定の場合, NO $x$ 除去率 $\eta$ は液流速の

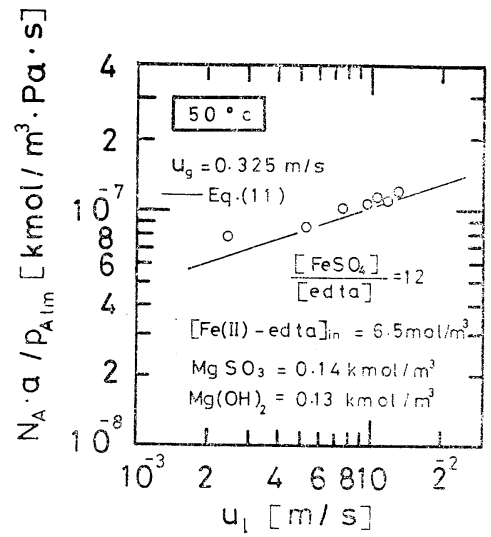

Fig. 12 Effect of $\mathrm{u}_{1}$ on $\mathrm{N}_{\mathrm{A}} \cdot \mathrm{a} / \mathrm{p}_{\mathrm{Alm}}$

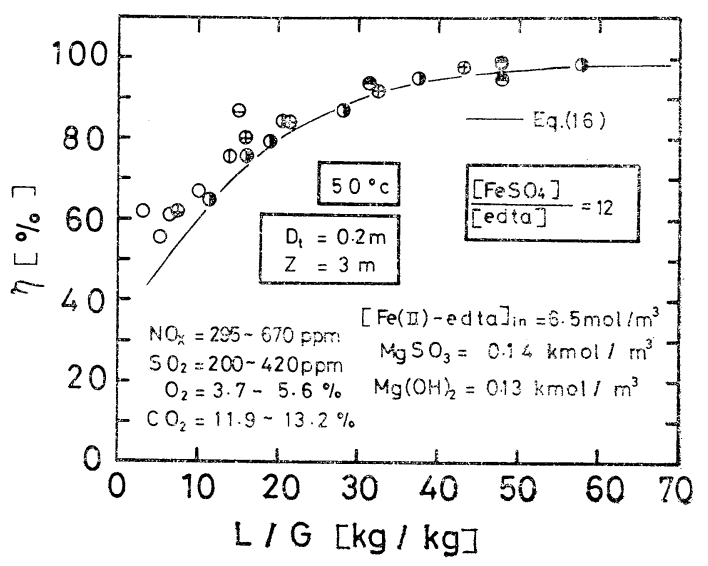

Fig. 13 Effect of $L / G$ on $\eta$

Table 3 Properties of suspended liquid

\begin{tabular}{|c|c|c|c|c|c|c|c|c|}
\hline \multirow{3}{*}{$\begin{array}{l}\text { Temp. } \\
{\left[{ }^{\circ} \mathrm{C}\right]}\end{array}$} & \multicolumn{4}{|c|}{ Liquid composition } & \multirow{3}{*}{$\begin{array}{l}o \times 10^{-3} \\
{\left[\mathrm{~kg} / \mathrm{m}^{3}\right]}\end{array}$} & \multirow{3}{*}{$\begin{array}{l}\mu \times 10^{3} \\
{[\mathrm{~Pa} \cdot \mathrm{s}]}\end{array}$} & \multirow{3}{*}{$\begin{array}{c}\mathrm{H} \times 10^{-4} \\
{\left[\mathrm{~Pa} \cdot \mathrm{m}^{3} / \mathrm{mol}\right]}\end{array}$} & \multirow{3}{*}{$\begin{array}{c}D_{\mathrm{NO}} \times 10^{9} \\
{\left[\mathrm{~m}^{2} / \mathrm{s}\right]}\end{array}$} \\
\hline & $\mathrm{FeSO}_{4}$ & edta & $\mathrm{MgSO}_{3}$ & $\mathrm{Mg}(\mathrm{OH})_{2}$ & & & & \\
\hline & {$\left[\mathrm{kmol} / \mathrm{m}^{3}\right]$} & {$\left[\mathrm{kmol} / \mathrm{m}^{3}\right]$} & {$\left[\mathrm{kmol} / \mathrm{m}^{3}\right]$} & {$\left[\mathrm{kmol} / \mathrm{m}^{3}\right]$} & & & & \\
\hline 50 & 0.06 & 0.005 & 0.14 & 0.13 & 1. 025 & 0.788 & 7.96 & 6. 498 \\
\hline 50 & 0.12 & 0.01 & 0.14 & 0.13 & 1. 031 & 0.84 & 7.96 & 6.095 \\
\hline 50 & 0.24 & 0.02 & 0.14 & 0.13 & 1. 052 & 0.945 & 8.00 & 5.42 \\
\hline
\end{tabular}


増加とともに高くなっている。すなわち, 気液接触面 積は Eq. (10) で示したように, 液流速の増加に伴な って増加するために, $\mathrm{NO}_{x}$ 除去率 $\eta$ にその影響が現 れたと考觉られる。Lが一定でGが增加すると，クは 減少している。G が増加すると, 気相容量係数 $\mathrm{k}_{\mathrm{G}}$ ・ a は増加するが，接触時間ぶ減少するため，この影響 がクに現われたためと考光られる。

迅速な不可逆擬一次反応を伴なら場合, 充垻塔の塔 高 Zは次式 ${ }^{10)}$

$$
\begin{aligned}
Z & =\frac{G_{M}}{k_{G} \cdot a \cdot P} \ln \frac{p_{A_{1}}}{p_{A_{2}}}+\frac{G_{M} \cdot H}{a \cdot P \cdot V \overline{D_{A} \cdot k_{1,1} \cdot C_{B O}}} \\
& \cdot \frac{1}{\mathrm{e}} \cdot \ln \frac{(\mathrm{e}+1) \cdot(e-b)}{(e-1) \cdot(e+b)}
\end{aligned}
$$

から求められる。ここで，e，b以それぞれ次式

$$
\begin{gathered}
\mathrm{e}=\sqrt{1+\mathrm{q}\left(\mathrm{p}_{\mathrm{A} 2} / \mathrm{p}_{\mathrm{A} 1}\right)} \\
\mathrm{b}=\sqrt{1+\mathrm{q}\left(\mathrm{p}_{\mathrm{A} 2} / \mathrm{p}_{\mathrm{A} 1}\right)-\mathrm{q}}
\end{gathered}
$$

で与えられている。な就，これらの式中の $q$ は次式

$$
\mathrm{q}=\left(\nu \cdot \rho_{\mathrm{M}} / \mathrm{P}\right) \cdot\left(\mathrm{G}_{\mathrm{M}} / \mathrm{L}_{\mathrm{M}}\right) \cdot\left(\mathrm{p}_{\mathrm{A}_{1}} / \mathrm{C}_{\mathrm{BO}}\right)
$$

で与光られる無次元の值である。ここに, $\mathrm{p}_{\mathrm{A}_{1}}, \mathrm{p}_{\mathrm{A}_{2} \text { 惊 }}$ それぞれ充填塔の入口と出口に和㐨る $\mathrm{NO}_{x}$ 分圧 $(\mathrm{Pa})$, $\mathrm{G}_{\mathrm{M}}$ はガスのモル流速 $\left(\mathrm{kmol} / \mathrm{m}^{2} \cdot \mathrm{s}\right), \mathrm{L}_{\mathrm{M}}$ は液のモ ル流速 $\left(\mathrm{kmol} / \mathrm{m}^{2} \cdot \mathrm{s}\right), \rho_{\mathrm{M}}$ は液のモル密度 $(\mathrm{kmol} /$ $\mathrm{m}^{3}$ ) である。また, レは化学量論数であり, NO と [Fe(II)-edta]との反応では, $\nu=1$ である ${ }^{1111}$ 。

ところで, $\mathrm{NO}_{x}$ 除去率は次式

$$
\eta=100 \cdot\left(1-\mathrm{p}_{\mathrm{A} 2} / \mathrm{p}_{\mathrm{A} 1}\right)
$$

で表される。Z が一定の場合の各操作条件に和ける $\mathrm{P}_{\mathrm{A} 2}$ を, Eqs. (12)〜(15) の関係式と操作条件, 反応 速度定数, 装置特性特よび諸物性值とから試行法で求 め, さらに, これを Eq.(16) に代入し, 得られたク の推定值をFig.13に実線で示した。実測值と推算値と の傾向はよく一致して和り, 本反応系の $\mathrm{NO}_{x}$ 除去率 の推算に際しては Eqs. (12)〜 (16) の関係を適用しら ることがわかった。な拉， $\mathrm{SO}_{2}$ の除去率は共存する $\mathrm{NO} x$ 濃度に関係なく液ガス比が 5 以上の条件では, 99\%以上であった。

\subsection{2 $\mathrm{NO}_{x}$ 吸收液の $\mathrm{NO}_{x}$ 吸収能力}

本吸収液による $\mathrm{NO}_{x}, \mathrm{SO}_{x}$ の吸収能力を明らかに するために，一定量の液を循環使用し， $\mathrm{NO}_{x}$ 除去率と 吸収持続時間之の関係求めた。

$\mathrm{Fe}$ (II)-edtaに, 亜硫酸塩としてそれぞれ, $\mathrm{MgSO}_{3}$ と $\mathrm{Na}_{2} \mathrm{SO}_{3}$ を加六た場合の, $\mathrm{NO}_{x}$ 除去率 $\eta$ と吸収時 間 $\theta$ との関係をFig.14に示した。なおこれらの吸収 液中の亜硫酸塩のモル濃度を同一とした。異なる亜硫 酸塩を用いた場合に执いても, 両者の関係は類似の偭

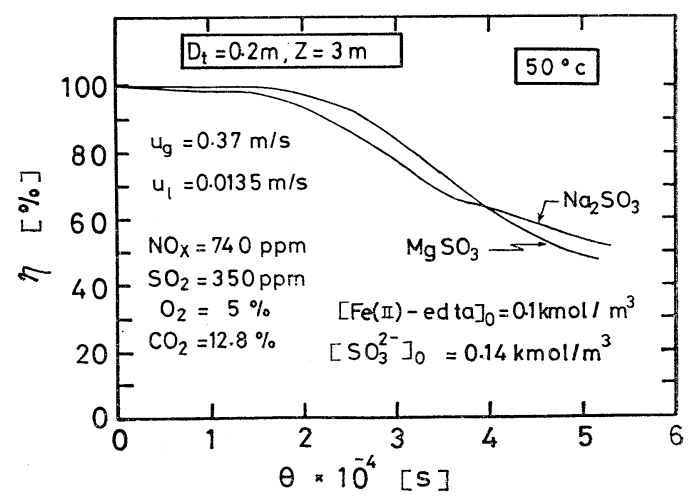

Fig. 14. Comparison of absorption efficiency between $\mathrm{Fe}(\mathrm{II})$-edta-MgSO $\mathrm{Mg}_{3}$ and

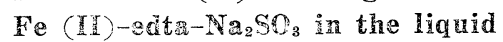

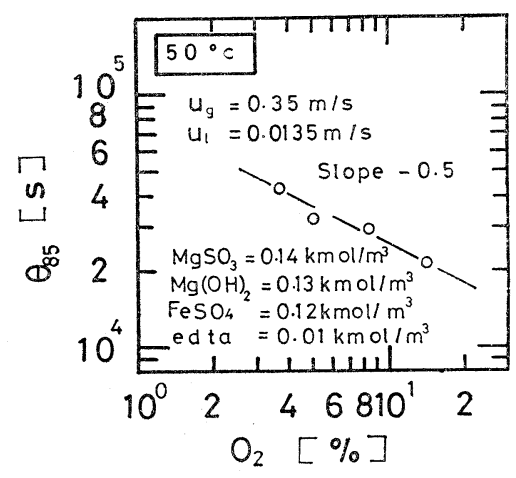

Fig. 15 Relation between $\theta_{85}$ and $\mathrm{OO}_{2} \mathrm{co}^{-}$ ncentration

向を示すことがわかった。

$\mathrm{NO}_{x}$ 除去率が初期除去率の $85 \%$ に低下するまでの 時間 $\theta_{85}$ もって, 吸収液の持つ $\mathrm{NO}_{x}$ 吸収能の有 效持続時間定義した ${ }^{22}$ 。この方法は, 実用の操作に 拉いて, 吸収液の $\mathrm{NO}_{x}$ 吸收能力を評価する際に意味 がある考劣られる。

Fig.15に $\theta_{85}$ と， $\mathrm{NO}_{x}$ と共存するガス中の $\mathrm{O}_{2}$ 浱 度との関係を示した。同図から， $\theta_{85}$ は $\mathrm{O}_{2}$ 濃度の0.5 乘に逆比例していることがわかった。また， $\mathrm{O}_{2}$ 濃度 の影響は装置形式の異なる前報2の結果とその傾向が 類似している。 $\theta_{85}$ と $\mathrm{NO}_{x}$ と共存する $\mathrm{SO}_{2}$ 濃度との 関係をFig.16に示した。同図から， $\theta_{85}$ は $\mathrm{SO}_{2}$ 濃度に よらず，ほ湆一定である。本吸収液は， $\mathrm{MgSO}_{3}-\mathrm{Fe}$ (II)-edta 系懸濁液に $\mathrm{Mg}(\mathrm{OH})_{2}$ 觉 $0.13 \mathrm{kmol} / \mathrm{m}^{3}$ 添 加しているので，前述のように， $\mathrm{SO}_{2}$ の $99 \%$ 以上は液 中に吸収されるが，そのほとんどは液中の $\mathrm{Mg}(\mathrm{OH})_{2}$ と反庆して $\mathrm{NE}^{\mathrm{C}} \mathrm{O}_{3}$ が生成されると考穴られる。した 


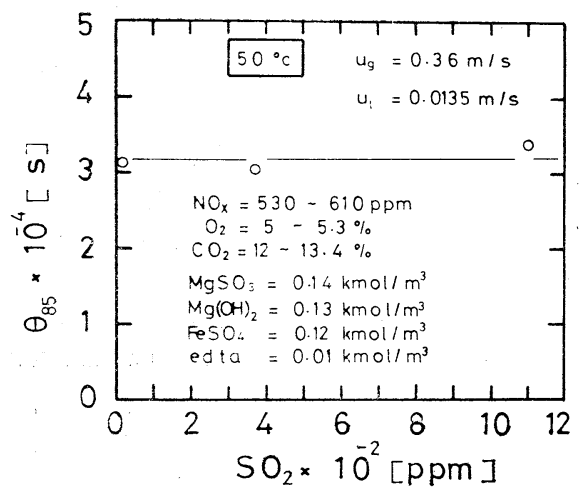

Fig. 16 The effect of $\mathrm{SO}_{2}$ concentration on $\theta_{85}$

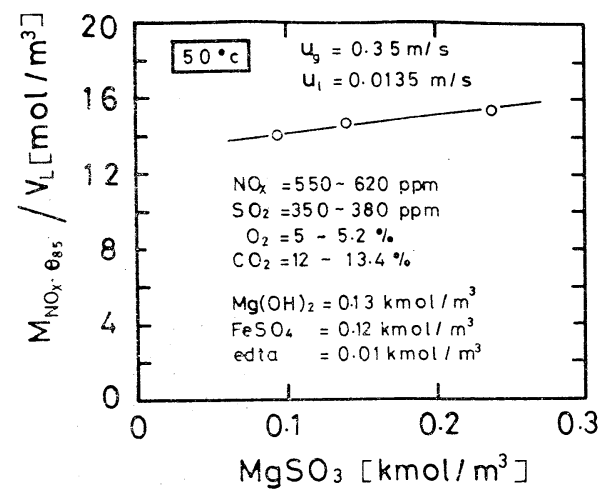

Fig. 17 Relation between $\mathrm{MNO}_{x}{ }^{\cdot \theta_{85}} / \mathrm{VL}_{\mathrm{L}}$ and $\mathrm{MgSO}_{3}$ concentration

がって, 排ガス中に数千 $\mathrm{ppm}$ 程度の $\mathrm{SO}_{2}$ が共存し ていても, 吸收液の $\mathrm{NO}_{x}$ 吸収能力は影響を受けない と思われる。

$\mathrm{NO} x$ 吸収能力の有効持続時間 $\theta_{85}$ までに吸収さ れた $\mathrm{NO}_{x}$ の吸収総量 $\mathrm{M}_{\mathrm{NO}} \cdot \theta_{85}(\mathrm{~mol})$ と吸収液量 $\mathrm{V}_{\mathrm{L}}\left(\mathrm{m}^{3}\right)$ との比 $\mathrm{M}_{\mathrm{NO}_{x}} \cdot \theta_{85} / \mathrm{V}_{\mathrm{L}}$ と $\mathrm{MgSO}_{3}$ の添加濃 度との関係を点綴し，Fig. 17 に示した。ただし， $\mathrm{MNO}_{\mathrm{N}} \cdot \theta_{85}$ は $\mathrm{NO}_{x}$ 除去率 $\eta$ と $\theta$ との関係から図積分 によって求めた。図示の関係から, $\mathrm{M}_{\mathrm{NO}_{x}} \cdot \theta_{85} / \mathrm{V}_{\mathrm{L}}$ は, $\mathrm{MgSO}_{3}$ 濃度が高いほど增加する傾向にあるが，その 増加の度合いは比較的小さいことがわかった。

本吸収液は edta 濃度に比べて Fe(II) の添加濃度 を過剩にしている。そこで, Fe (II) と edta の濃度 此を一定にして， $\mathrm{Fe}$ (II) と edta の濃度を变化させ， $\mathrm{M}_{\mathrm{NO}} \cdot{ }_{\theta_{85}} / \mathrm{V}_{\mathrm{L}}$ と edta 濃度との関係を点緅し, Fig. 18に示した。 $\mathrm{M}_{\mathrm{NO}} \cdot \theta_{85} / \mathrm{V}_{\mathrm{L}}$ は, edta 濃度が高くな ると増加している。しかし, edta 濃度が $0.01 \mathrm{kmol} /$ $\mathrm{m}^{3}$ 以上になると，それ以下の濃度に比べて増加の度合

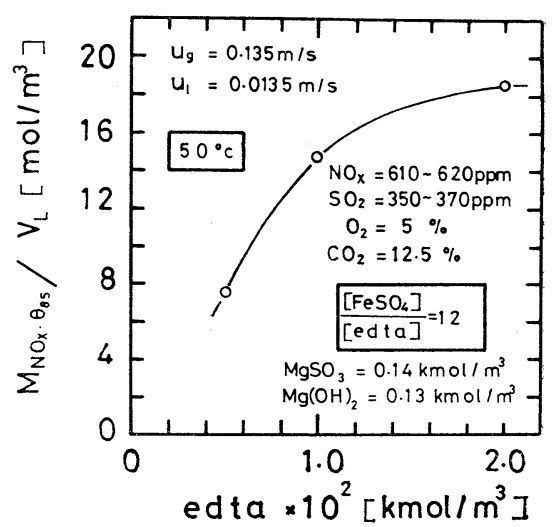

Fig. 18 Relation between $\mathrm{MNO}_{\boldsymbol{x}} \cdot \theta_{85} / \mathrm{V}_{\mathrm{L}}$ and edta concentration

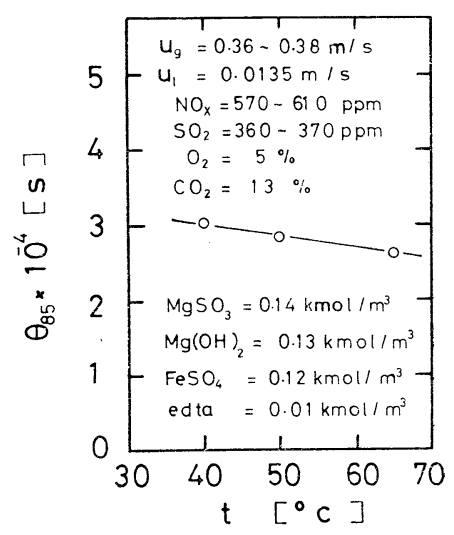

Fig. 19 The effect of temperature on $\theta_{85}$

いは小さくなっている。edta濃度を増すと吸収液中の $\mathrm{Fe}$ (II) ならびに $\mathrm{MgSO}_{3}$ の溶解度は大さくなる1。 したがって，Fig.18に図示の結果は，吸収液中の Fe (II), $\mathrm{MgSO}_{3}$ の酸化が $\mathrm{O}_{2}$ によって促進されたため 現われたと考えられる。

Fig.19に $\theta_{85}$ と温度との関係を示した。 $\theta_{85}$ に特よ ぼす温度の影響としては，NO 錯体の生成定数に対す る影響, 亚硫酸根と NO 特よび $\mathrm{Fe}$ (III) との反応速 度に対する影響，また， $\mathrm{O}_{2}$ と $\mathrm{Fe}(\mathrm{II})$ との反応速度 に対する影響などが考学られる。NO 錯 体の生成定 数は温度が高くなると減少することが認められている 6)11)。したがって，温度が高くなると，吸収液の NO 吸収能は低下する。また， $\mathrm{O}_{2}$ による $\mathrm{Fe}$ (II) の酸化 速度は温度が高くなると増加する2) ので吸収液中の $\mathrm{Fe}$ (II)-edta 濃度は減少し，NO の吸収速度，すな わち NO の除去率は低下する。一方, 亚硫酸根によ る $\mathrm{Fe}$ (II)-edta に配位した NO および Fe (III) の 


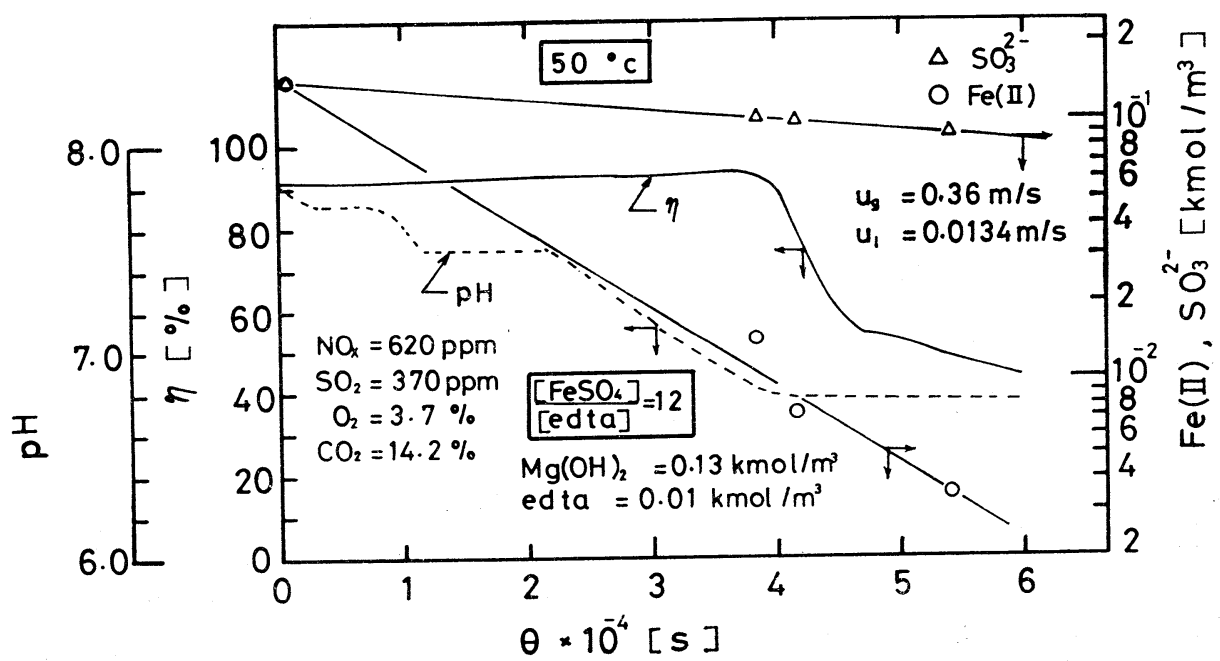

Fig. 20 Decreases in NOx absorption efficiency, $\mathrm{pH}$, the concentration of $\mathrm{MgSO}_{3}$ and $\mathrm{Fe}$ (II) with time in recycling operation of the liquid

還元速度は温度が高くなると增加することが認められ ている7)8)。しかし，本吸収反応の初期の段階では， これらの還元反応に比べて $\mathrm{O}_{2}$ による $\mathrm{Fe}$ (II) の酸 化反応が支配的である( ${ }^{(2) 8) 。 以 上 の こ と か ら ~} \theta_{85}$ は温 度が高くなると減少する傾向を示すと思われる。Fig. 19 亿図示した $\theta_{85}$ と温度との関係に，これらの影響が 現われて扮り，影は温度が高くなると減少している。 また，図示の結果は前報2) の結果から推定した $\theta_{85}$ と 温度との関係とその傾向が類似している。したがっ て，装置形式が異なっても， $\theta_{85}$ に扮よぼす温度の影 響の現われ方は同様で㐫ることがわかった。

Fig. 20 にと $\theta$ との関係の一例を示した。同図 中に吸収液貯槽中の吸収液の，それぞれ， $\mathrm{pH}, \mathrm{Fe}$ (II)，抢よび $\mathrm{SO}_{3}^{2}$-濃度と， $\theta$ との関係を示した。 $\mathrm{pH}$

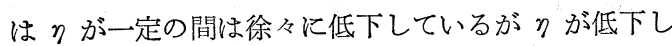
はじめると, $\mathrm{pH}$ は 6.8 のほぼー定值に近づく。同図 飞, $\mathrm{Fe}(\mathrm{II}), \mathrm{SO}_{3}^{2-}$ 濃度と $\theta$ との関係を片対数紙上 に点経して示したが, これの関係は, 注ぼ直線で近似 できる。したがって，本吸収液中の $\mathrm{Fe}$ (II) 拉よび $\mathrm{SO}_{3}^{2}$ の減少速度は, 見掛上, それぞれの濃度のほぼ 一次に比例している。

以上の結果から実用の連続操作を考慮すると, $\mathrm{O}_{2}$ 濃度が $5 \%$ 以上の場合, 吸收液中の錯体拉よび $\mathrm{MgSO}_{3}$ の添加濃度を必要以上に高めることは得策でないこと がわかった。また, 懸濁液濃度が 2 5 wt \% の範团で は，懸濁粒子による装置内の閉塞は認められなかっ た。

\section{5. 結 言}

凹仪剤として $\mathrm{MgSO}_{3}-\mathrm{Mg}(\mathrm{OH})_{2}-\mathrm{Fe}$ (II)-edta 系懸 濁液を用い，充填物としてサンパッキンを用いた充填

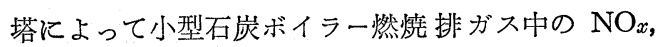
$\mathrm{SO}_{x}$ の同時除去パイロット試験を行った。また, 本装 置の気相物質移動保数と気液接触面積のそれぞれを, 不可逆擬一次迅速反応を伴なら $\mathrm{CO}_{2}-\mathrm{NaOH}$ 水溶液系 の吸収実験より求め, これらに拉よぼすガス流速, 液 流速の影響を明らかにした。得られた結果は以下のよ らである。

1） $\mathrm{NO}_{x}$ 除去率は液ガス比が $30 \mathrm{~kg}$-liquid $/ \mathrm{kg}$-gas 以上になると，90\%程度まで達成しうることがわかっ た。吸收液中に少量の $\mathrm{Mg}(\mathrm{OH})_{2}$ を添加することに よって排ガス中の $\mathrm{SO}_{2}$ の99\%以上は除去された。し たがって，本吸収液は石炭然焼排ガスのようにきわめ てダーティな排ガスにも十分適用できる見通しを得 た。

2）本装置内の $\mathrm{NO}_{x}$ 吸収反応は迅速な不可逆擬一 次反応として進行していることがわかった。

3） $\mathrm{NO}_{x}$ 除去率は, Eqs. (12) (16) を用いて推定 しうることが明らかになった。をた， $\mathrm{NO}_{x}$ 除去率は排 ガス中に共存する $\mathrm{SO}_{x}, \mathrm{O}_{2}, \mathrm{CO}_{2}$ によってほとんど 影響されないことがわかった。

4）懸濁液の濃度が 2 5wt\% の範囲では, 懸濁粒 子による装置の閉塞は認められなかった。

5）本吸収液による $\mathrm{NO}_{x}$ 吸収の有効持続時間に和 よぼす酸素濃度の影響は, 装置形式の異なる基礎試験 
の結果と類似した傾向を示した。

6）気相物質移動 係 数は無次元式, Eq. (9), ま た，気液接触面積は実験式，Eq. (10) で整理された。 文献

1）福田, 池田; 井戸川, 安藤, 然協誌, 59, (637), 329 (1980)

2）福田, 池田, 斗戸川, 安藤, 燃協誌, 59, (641), 750 (1980)

3）福田, 化学工学論文集, 7, (2), 171 (1981)

4) 正田, 浅井, 化学工学, 28, 1017 (1964)

5) 化学工学協会編, 化学工学便覧, p. 484, 丸善書 店 (1968)

6）田中, 小泉, 石原, 電力中央研究所報告, 275017 (1976)

7) 田中, 小泉, 横山, 石原, 電力中央研究所報告,
276027 (1977)

8）佐藤，横島，岡部，日化，(2)，181(1980)

9) K. Onda, H. Takeuchi, Y. Okumoto, J. Chem. Eng. Japan, 1, 56 (1968)

10) K. E. Porter, Trans. Inst. Chem. Engrs., 41, 320 (1963)

11) M. Teramoto, S. Hiramine, Y. Shima, $Y$. Sugimoto, H. Teranishi, J. Chem. Eng. Japan, 11, 450 (1978)

12）“日本工業規格”，M-8212（1971），日本規格協会 編

13）“日本工業規格”，M-8213（1971），日本規格協会 編

14) C. E. Wales, A.I.Ch.E.J.,12, 1166 (1966)

\title{
A Pilot Test of Simultaneous Removal of NOx and SOx from the Flue Gas of Coal-Fired Boiler
}

\author{
Kiyoshi IDogawA, Koji IKedA and Takashi FukUdA \\ (Government Industrial Development Laboratory, Hokkaido)
}

SYNOPSIS: - Simultaneous removal of $\mathrm{NO}_{x}$ and $\mathrm{SO}_{x}$ from the flue gas was performed under the gas feed rate from 50 to $80 \mathrm{Nm}^{3} / \mathrm{hr}$ using the slurry liquid of $\mathrm{MgSO}_{3}-$ $\mathrm{Mg}(\mathrm{OH})_{2}-\mathrm{Fe}$ (II) - edta system in a column packed with "SAN" packing.

It was shown that the removal ratio of $\mathrm{NO}_{x}$ exceed $90 \%$ for liquid-gas ratio above $30 \mathrm{~kg}$-liquid $/ \mathrm{kg}$-gas. More than $99 \%$ of $\mathrm{SO}_{2}$ was removed. It was found that $\mathrm{NO}_{x}$ removal ratio can be estimated by means of Porter's equation.

As the results, deposition of solid particles in the apparatus does not occur when concentration of solid particles in the slurry liquid is in the range of 2-5\%. Any increase in the initial concentration of $\mathrm{MgSO}_{3}$ or $\mathrm{Fe}$ (II)-edta increases $\mathrm{NO}_{x}$ absorption capacity of the absorbing liquid.

$\mathrm{NO}_{x}$ absorption capacity of the liquid did not increased so much at $\mathrm{O}_{2}$ cocentration above $5 \%$ when the concentration of $\mathrm{MgSO}_{3}$ and $\mathrm{Fe}$ (II)-edta in the liquid were increased. 